\title{
MIGRANT FAMILIES IN A REGIONAL VIEW
}

Sigita Sulca ${ }^{1}$, PhD student; Ance Cerina ${ }^{2}$

${ }^{1}$ University of Latvia, Faculty of Geography and Earth Sciences; ${ }^{2}$ Central Statistical Bureau of Latvia

Abstract. In Latvia the process of migration has a significant impact on population and its composition. Population decreases, due to most emigrants being of working age and fertile age, when people establish a family. Over the last years, return processes have become more apparent. Since various groups are being involved in migration, this paper focuses on different types of emigrant and remigrant families with children.

The research aims to characterise types of Latvian families with children that have emigrated and returned over the last six years. The results are derived from Population Register data and Central Statistical Bureau (CSB) Population Assessment Method data.

Latest data show that number of women and children among immigrants has increased and this research confirms that women with children are the most prevalent group in both emigration and remigration. The most attractive region for remigratnt families is the Riga region.

Key words: Emigrants, remigrants, regions, families.

JEL code: R23.

\section{Introduction}

Migration significantly affects population size, distribution and composition. Migration processes are influenced by economic and political processes. As the global economic and political situation changes, the nature and types of migration also change. Economic migrant flows are diminishing due to increased welfare, multiple places of residence, studying, as well as identity searches (Brooks R., Waters J., 2011; Holloway SI., et al., 2012; Cresswell T., 2011; Mierina, I. 2015). Not only the nature of emigration but also the flows and causes of remigration are changing.

Since the early 1990s, Latvia has had a negative net migration. The volume of emigration has stabilised during 2012-2017 and accounts for about $1 \%$ of Latvia's population. Data on Latvian remigrants (citizens, non-citizens and born in Latvia) from 2012 - 2017 (CSB unpublished data) reveal that most are women and the proportion of children aged below 15 is increasing. During this period the amount of immigration has not exceeded $0.5 \%$ of the total population of Latvia. The dynamics of Latvian national's remigrants among immigrants since 2012 range from $85.7 \%$ (2012) to $55 \%$ (2017) and the trend is not upward (Figure 1). Due to high share of remigrants among immigrants, it is necessary to focus on this group.

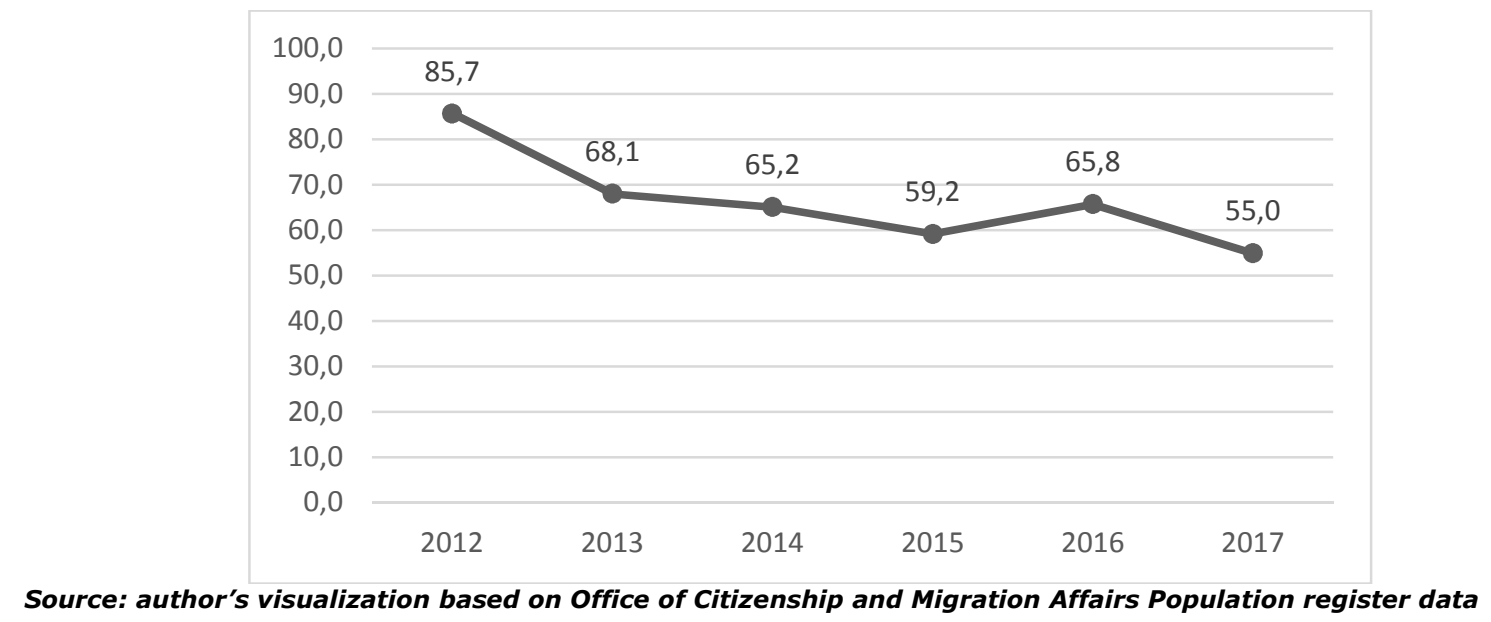

Fig. 1. Share of remigrants among immigrants $2012-2017, \%$

\footnotetext{
${ }^{1}$ Sigita.shultz@gmail.com 
The aim of this study is to investigate regional (Statistical regions of Latvia) patterns of emigrant and remigrant families with children using only administrative registers.

This study analyses emigration and remigration patterns with an emphasis on families. Numerous studies in Latvia have focused on various facets of migration, for example, diaspora, migration flows and directions after the EU enlargement (Lulle A., Klave E., 2015; Mierina (ed.), 2015; McCollum et al., 2017). Nevertheless, families with children have never been the main focus of research. Based on that, the main research questions of this study are: 1) To characterise composition of emigrant and remigrant families with children from 2012 to 2017. 2) Analyse the number of children in emigrant and remigrant families in on regional scale. 3) Distribution of emigrant and remigrant families among regions of Latvia.

To describe the concept of remigration in Latvia, different definitions are used, for example, reemigration (Klave E., 2016) and return migration (Ministry of Foreign Affairs, 2014). Remigration is often characterised as the end of the migration process, when the individual returns to his or her country of origin (Oliver - Mensah C., Scholl-Schneider S., 2016, 2).

The topicality of remigration in Latvia is increasing every year, since majority of the emigrants are of working age and fertile age. The country is interested in their return (MEPRD, 2018). A special state aid program was launched in 2018 (MEPRD, 2018; Cabinet of Ministers Regulations, 2018) for Latvian nationals who have lived abroad for more than three years or have recently returned. The first results on effect of program on amount of returnees will be available in June 2019.

\section{Data and methods}

Data on migrants were derived from Administrative Data Sources for a time span of 2012 to 2017. Data of Population Register of the Office of Citizenship and Migration Affairs (OCMA) included characteristics, such as gender, age, country of birth, marital status, citizenship, declared place of residence and was adjusted according to the method of assessment of declared place of residence. The CSB Population Assessment Method (CSB, 2012) was used to categorize emigrants and returnees as well.

In order to identify the number of children in the families of emigrants and returnees, two criteria of data selection were utilised. Firstly, the age limit of 18 years and, secondly, the condition of at least one parent being a citizen or non-citizen or born in Latvia. Returnees to Latvia were defined using both data from the OCMA Population Register and from the CSB method, including those individuals who had the highest probability of living in Latvia (1); whereas emigrants had the lowest probability (close to 0 ).

Datasets of emigrants and returnees were divided into subsets for each year (as of $31^{\text {st }}$ December) - Firstly, only Latvian nationals (incl. Latvian citizens, Latvian non-citizens, persons born in Latvia). Secondly, subset - of children aged between 0 - 18 years. Thirdly, parents' personal IDs were checked in the emigrants and immigrants' data set and added to children's data set. The following scheme (Fig. 2) summarises aggregated family types in accordance with characteristics of data. 


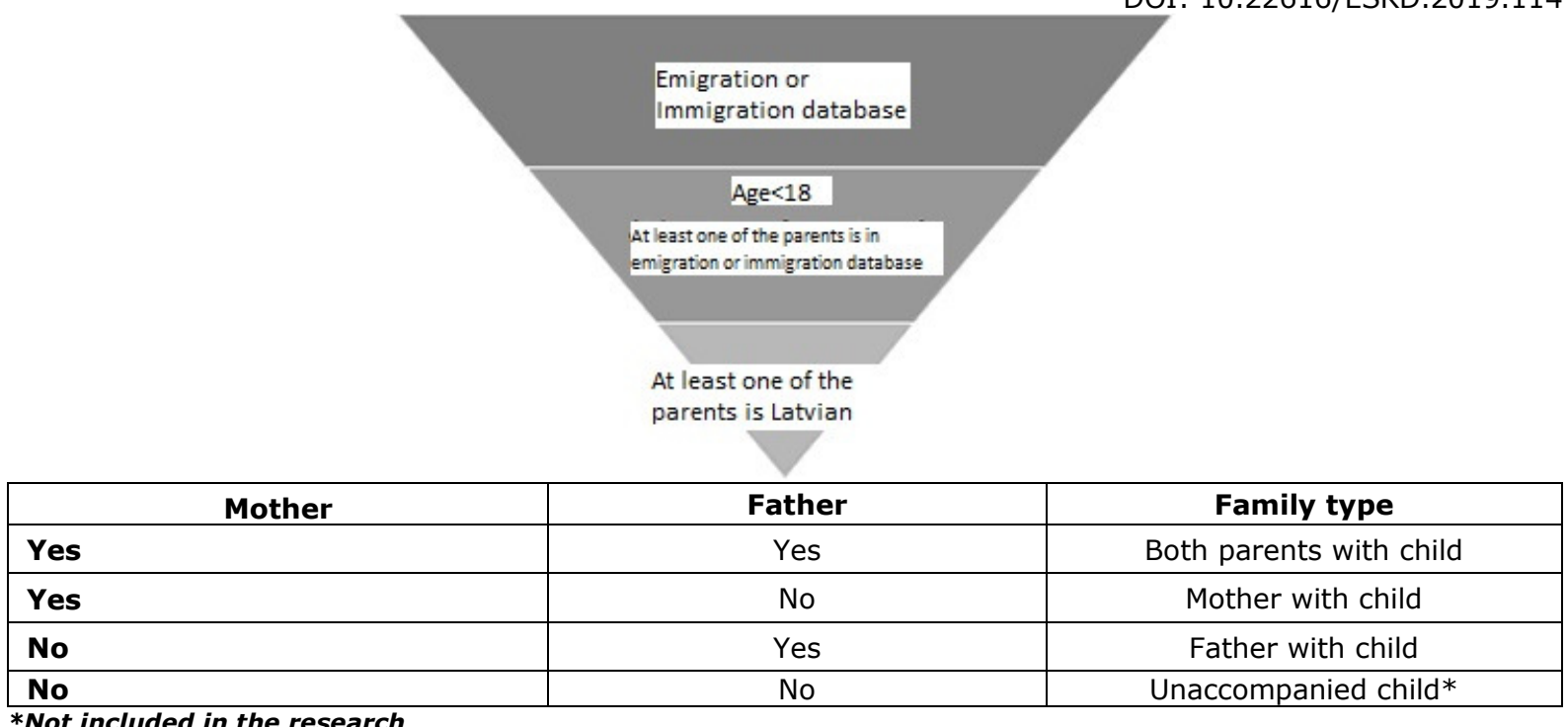

*Not included in the research

Fig. 2. Scheme of dividing taxonomy of Latvian emigrants and returnees to Latvia

Descriptive statistics were used to characterise the composition of returnee families and their distribution among the regions.

It should be taken into account, using of administrative data is influenced by some specific features - for instance, in case of emigration, part of the population does not change the declared place of residence and does not announce the other address abroad. Moreover, often during the first years after emigration, person is present in other administrative registers of Latvia - they go to the doctor, change documents (driving license, passport), study or still receive benefits or some social services.

\section{Research results and discussion}

Latvia has lost more than 125,000 inhabitants due to emigration during the period from 2012 2017. 5706 families with children from Latvia (Latvian nationals) emigrated and only 2178 returned during mentioned period. Mother with children is the dominant family type for both emigration and remigration. This family type constitutes more than $70 \%$ of all families (Fig. 3). The share of families with both parents and children in emigration and remigration is similar- around $14 \%$.
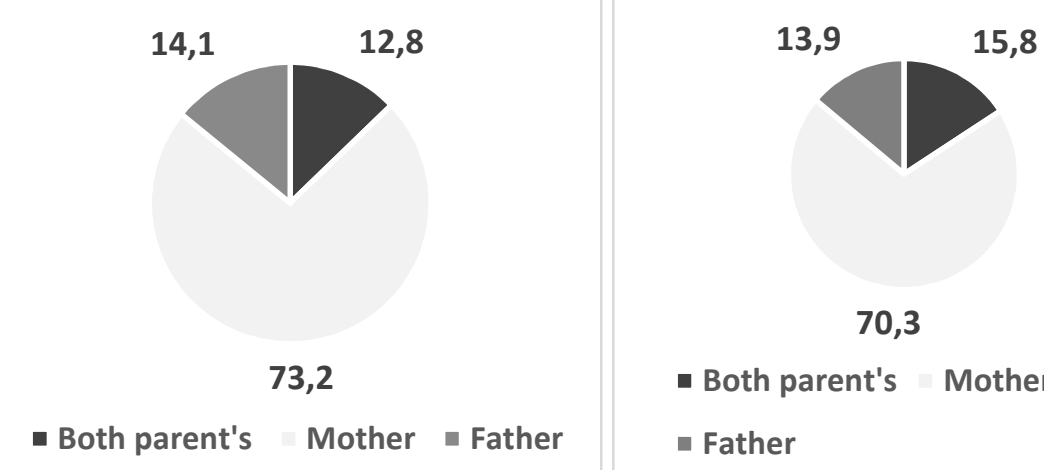

- Both parent's Mother

- Father

Source: author's visualization based on Office of Citizenship and Migration Affairs Population register data

Fig. 3. Types of emigrant (left) and remigrant (right) families with children $2012-2017$, (\%)

In both cases, the share of women with children is higher than $70 \%$. It can be assumed that women with children return first. Such assumption confirms that women with children are more prone to make a decision on emigration or return and women take care of children and more often try to be with them. 
Concerns about raising school-age children can often be essential when making a decision on migration (emigration or remigration), or they may be the main argument for its timing or postponement (Tomic C. H., Pichler R., 2018). There are various reasons for women remigration, one of them being the fact that living abroad does not improve material conditions and also leads to spending less and less time with family, especially children (Dyer, McDowell, and Batnitzky's (2011, 685), Yeoh, Brenda S. A., and Kamalini Ramdas. 2014).

The observation of dynamics of family size from 2012 - 2017 (Figure 4), shows that trends are sTable - more than $75 \%$ of all emigrant families of Latvian citizens are families with one child, about $20 \%$ are families of two children and almost $4 \%$ are families with three or more children.

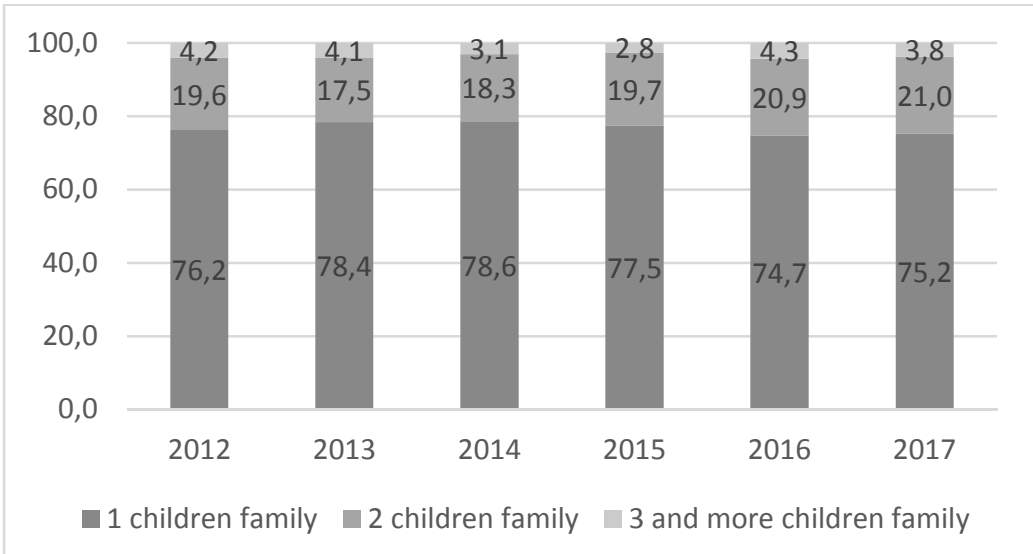

Source: author's visualization based on Office of Citizenship and Migration Affairs Population register data

Fig. 4. Emigrant families with children by size, 2012-2017, \%

Compared to 2012, the number of families with one child has decreased, when it comes to the total number of returnees, while the proportion of families with two and more children has increased (Fig. 5).

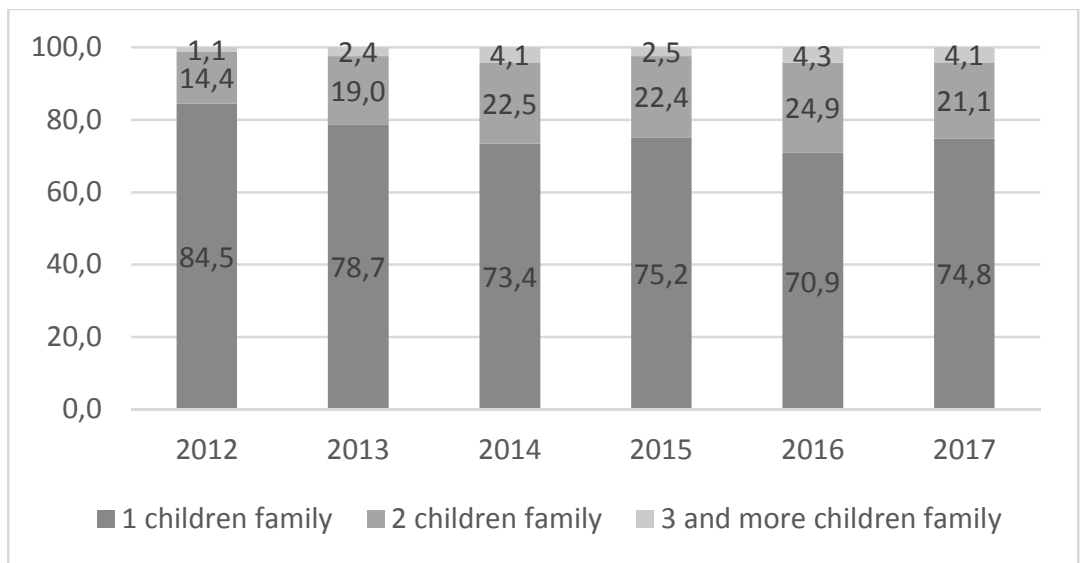

Source: author's visualization based on Office of Citizenship and Migration Affairs Population register data

Fig. 5. Remigrant families with children by size, 2012-2017, \%

Regarding family size in emigration and remigration, there are tendencies that indicate the largest difference observed (Table 1) relates to families with two children - the proportion of such families among remigrants is more than among emigrants. This applies to emigrant families with both parents and one parent emigrant families. Families with only one child dominate both among emigrants and remigrants, since parents in these families are younger, and, conversely, it is easier (from psychological and emotional standpoint) to make decision of migration. Besides, in material terms, these families are less at risk of poverty. It is a concern that there is a relatively small proportion of large families among the returnees. 
Family composition and number of children $2012-2017, \%$

\begin{tabular}{|l|c|c|c|c|c|c|}
\hline \multirow{2}{*}{$\begin{array}{c}\text { Number of } \\
\text { children in } \\
\text { family }\end{array}$} & \multicolumn{3}{|c|}{ Emigration } & \multicolumn{3}{c|}{ Remigration } \\
\cline { 2 - 7 } & $\begin{array}{c}\text { Both } \\
\text { parent's }\end{array}$ & Mother & Father & $\begin{array}{c}\text { Both } \\
\text { parent's }\end{array}$ & Mother & Father \\
\hline $\mathbf{1}$ & 72.8 & 80.5 & 82.1 & 67.4 & 77.0 & 80.9 \\
\hline $\mathbf{2}$ & 18.5 & 16.4 & 15.1 & 27.6 & 20.2 & 16.8 \\
\hline $\mathbf{3 +}$ & 8.6 & 3.1 & 2.8 & 5.0 & 2.8 & 2.3 \\
\hline
\end{tabular}

Source: author's calculations based on Office of Citizenship and Migration Affairs Population register data

Data on distribution of emigrant families with children among the regions of Latvia shed light on Riga region as the main region of departure for families with children in all family types (Fig 5). Especially of mother and child family - more than $20 \%$ of all emigrant families with children emigrated from Riga region. Data on number of children in emigrant families' shows similar tendency - most of families with children emigrated from Riga region, especially families with one children.

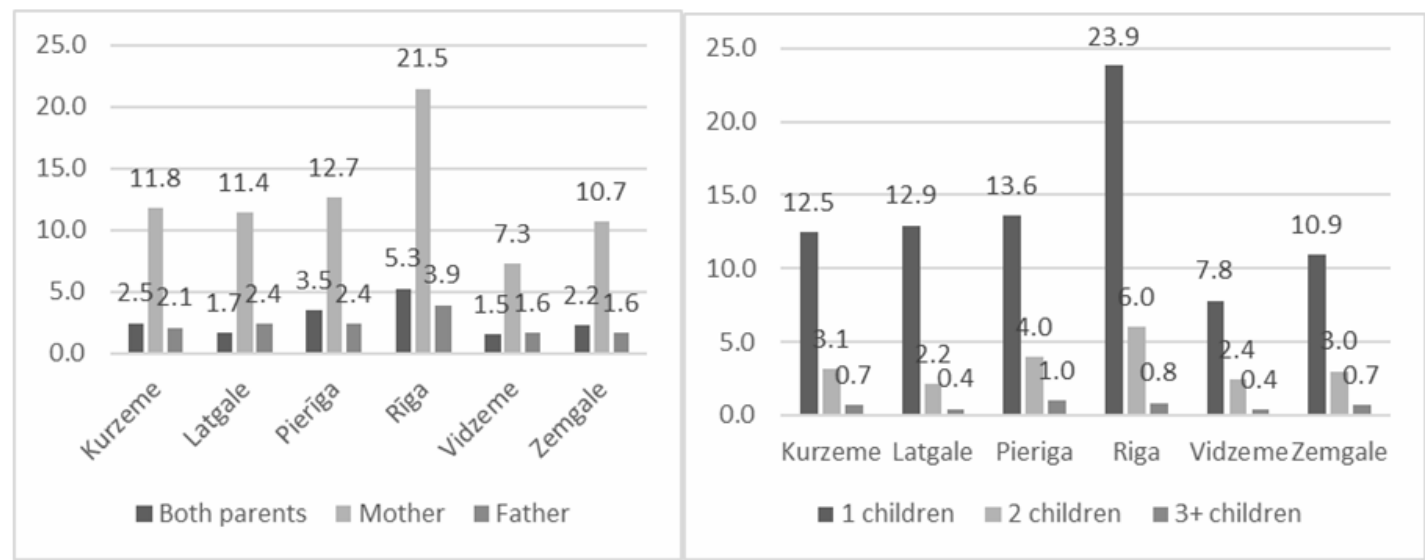

Source: author's visualization based on Office of Citizenship and Migration Affairs Population register data

Fig. 6. Emigrant families with children by type, by number of children and by region 2012 2017, \%

The lowest proportion of families with children in emigrants is from Vidzeme. Riga region is the leading region regarding remigration of mother and child family type - around $20 \%$ of all remigrant families, which is constituted by mother and child return to Riga region. Latgale and Vidzeme regions are less attractive for remigrants (Fig. 6 and Fig. 7).
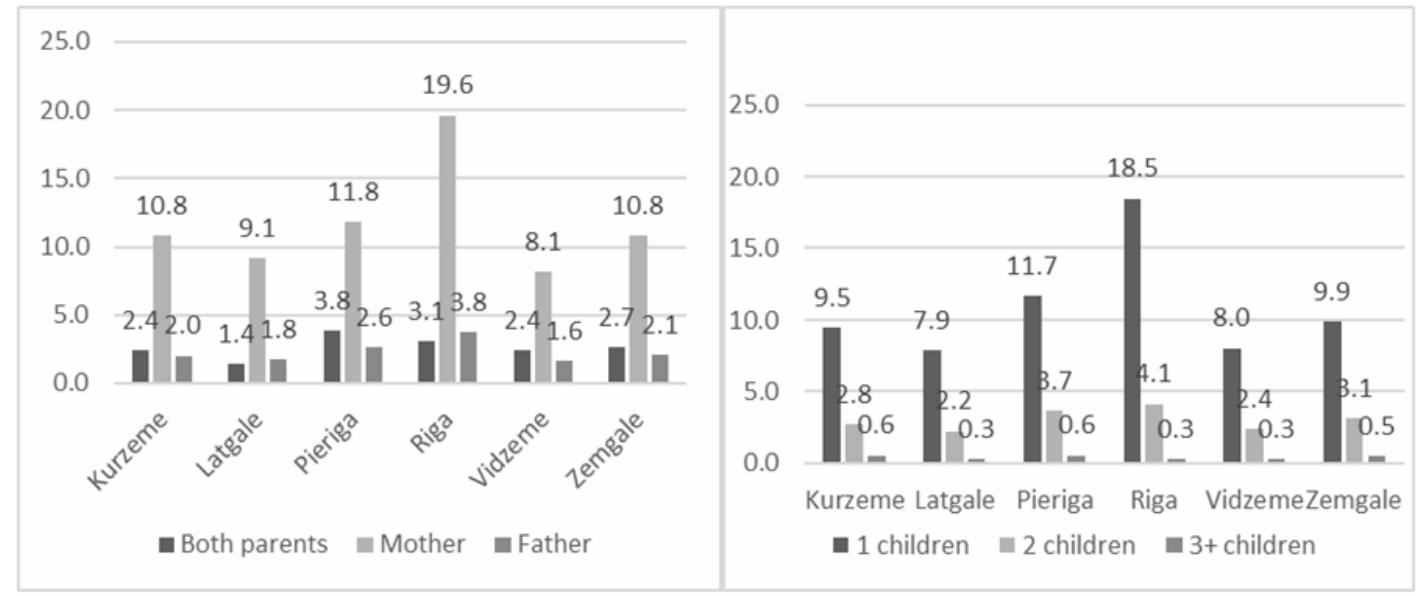

Source: author's visualization based on Office of Citizenship and Migration Affairs Population register data

Fig. 7. Remigrant families with children by type, by number of children and by region 2012 2017, \% 
Most often remigrants return to Riga region, typically - families with one child, the second most popular region is Pieriga region.

\section{Conclusions, proposals, recommendations}

1) Emigration and immigration have stabilised over the past six years, whereas the amount of returnees to Latvia (Latvian nationals) - remigrants in total immigration do not exceed $60 \%$ and the trend is not upward.

2) Analysing composition of families by type (for groups such as both parents with children, mother with children and father with children) in migrant data shows that the family type of mother with children, which constitutes more than $70 \%$ of all families, is the most prevalent one.

3) The data on emigrant and remigrant families show that one or both parents with one child are more involved in migration processes, due to the fact that parents are often younger, which, in turn, facilitates migration. It can be assumed that families with two or more children rarely decide to emigrate because it is more complicated, both psychologically and financially.

4) Distribution of emigrant families among regions is uneven. Riga region is the main region of departure for families with children of all family types. Remigration volumes in the country are generally decreasing, however, there are regions and territories that are more attractive for remigrants, namely Riga and Pieriga. Families with children choose these regions to resume their lives in Latvia, because infrastructure and services meet their requirements. Riga region has the largest share of emigrant and remigrant families of mothers with children. The lowest proportion of families with children in migration is from Vidzeme.

5) Analysis of remigrant families confirms that the return of women and children is increasing and that the number of returning families with more than one child is also increasing. For most families, it is important that children acquire education in Latvia, so it can be assumed that families with young children are more likely to return. It is very important for these people to receive support when it comes to making a decision to return, and to help them settle household issues after their return.

6) Importance of Riga region as a destination for remigration flows can be witnessed as the women with children is the most prevalent group among immigrants. Therefore, the immigration pattern can be linked with the presence of infrastructure, and the capacity of services suiTable for family needs.

\section{Bibliography}

1. Brooks, R, Waters, J (2011). Student Mobilities, Migration and the Internationalization of Higher Education. 208 pages. Palgrave MacMillan, Basingstoke 15 Apr 2011. ISBN: 9780230578449. http:/,/www.palgrave.com/products/title.aspx?pid=345888. Access: 15.01 .2019

2. Cresswell, T., (2011). Mobilities I: Catching Up. Progress in Human Geography. 35. 550-558. 10.1177/0309132510383348. Access: 20.12.2018

3. CSB unpublished data on immigrants by nationality from 2012 to 2017.

4. CSB (2012). Method Used to Produce Population Statistics. Central Statistical Bureau of Latvia Riga, Latvia: https://www.csb.gov.Iv/sites/default/files/data/LV/DemStat_Metodologija_LV.pdf. Access: 13.12.2018

5. CSB (2017) Portrait of Emigrant; 2014-2016, Central Statistical Bureau of Latvia: https://www.csb.gov.Iv/en/statistics/statistics-by-theme/population/migration/search-in-theme/342portrait-emigrant-2014-2016-only-latvian. Access: 11.01.2019

6. Dyer, S., McDowell, L., Batnitzky, A., (2011). Migrant Work, Precarious Work-life Balance: What the Experiences of Migrant Workers in The Service Sector in Greater London Tell As About The Adult Worker Model. Gender Place and Culture. 18. 685-700. 10.1080/0966369X.2011.601808.

7. Holloway, SL, O'Hara SL and Pimlott-Wilson H (2012). Educational Mobility and The Gendered Geography of Cultural Capital: The Case of International Student Flows Between Central Asia and The UK. Environment and Planning A, 44 (9), pp. 2278-2294 
8. IOM (2017) World Migration Report 2018, International Organization for Migration, DOI: $10.22616 / E S R D .2019 .114$ https://publications.iom.int/system/files/pdf/wmr_2018_en.pdf. Access: 15.01.2019

9. Klave, E., (2016) Reemigrācijas politikas novērtējums: politikas mērka grupas perspektīva, LU Filozofijas un Socioloǵijas institūts p. 1. - 40.

10. Lulle, A., Klave, E., (2015) Radot iespējas attīstībai: diasporas bērnu un jauniešu izglītība, Latvijas Universitātes Diasporas un migrācijas pētījumu centrs, LU Akadēmiskais apgāds p. 174. - 219.

11. Lulle, A., (2018) Mobilities and waiting: experiences of middle-aged Latvian women who emigrated and those who stayed put, Gender, Place \& Culture, 25:8, 1193-1208, DOI: 10.1080/0966369X.2018.1435512. Access: 13.12 .2018

12. McCollum, D., Apsite-Berina, E., Berzins, M., Krisjane, Z. (2017). Overcoming the crisis: the changing profile and trajectories of Latvian migrants. Journal of Ethnic and Migration Studies, 43(9), 1508-1525. DOI: 10.1080/1369183X.2016.1232161. Access: 15.01.2019

13. MEPRD (2018). Project "Reǵionālais remigrācijas koordinators": https://www.paps.lv/ Access: 15.01.2019

14. Mierina, I. (2015). Latvijas emigrantu kopienas: cerību diaspora. Latvijas Universitātes aǵentūra" Latvijas Univeristātes Filozofijas un socioloǵijas institūts".

15. Ministry of Foreign Affairs, (2014) Rīcības plans Par sadarbību ar Latvijas diasporu 2015.-2017. gadam, Ârlietu ministrija

16. Oliver - Mensah C., Scholl-Schneider S., (2016). Transnational Return? On The Interrelation of Family, Remigration, and Transnationality - An Introduction, Transnational Social Review, 6:1 - 2, 2 - 9, DOI: 10.1080/21931674.2016.1186371: https://doi.org/10.1080/21931674.2016.1186371 Access: 13.12 .2018

17.Tomic, C.T., Pichler, R., (2018) Remigration to Post-Socialist Europe: Hopes and Realities of Return, ERSTE Foundation Series, Volume 3).

18. Yeoh, B.S.A., Kamalini, R., (2014). "Gender, Migration, Mobility and Transnationalism." Gender, Place \& Culture 21 (10): 1197-1213. doi:10.1080/0966369X.2014.969686. Access: 13.12.2018 